\title{
Who Pays a Price on Carbon?
}

\author{
Corbett A. Grainger · Charles D. Kolstad
}

Accepted: 19 February 2010 / Published online: 30 March 2010

(C) The Author(s) 2010. This article is published with open access at Springerlink.com

\begin{abstract}
We use the 2003 Consumer Expenditure Survey and emissions estimates from an input-output model based on the 1997 US economy to estimate the incidence of a price on carbon induced by a cap-and-trade program or carbon tax in the context of the US. We present results on how much different income deciles pay for a carbon tax as well as which industries see the largest increase in costs due to a carbon tax. We illustrate the main determinant of the regressivity: consumption patterns for energy-intensive goods. Furthermore, on a per-capita basis a carbon price is much more regressive than calculations at the household level. We discuss policy options to offset the adverse distributional effects of a carbon emissions policy.
\end{abstract}

Keywords Distributional incidence $\cdot$ Carbon tax $\cdot$ Tradable permits

JEL Classification Q52 $\cdot \mathrm{Q} 58 \cdot \mathrm{H} 22$

\section{A. Grainger $(\bowtie)$}

Department of Economics, University of California, Santa Barbara,

CA, USA

e-mail: grainger@econ.ucsb.edu

URL: http://www.econ.ucsb.edu/ grainger

C. A. Grainger

Department of Agricultural and applied Economics,

University of Wisconsin, Madison, USA

C. D. Kolstad

Department of Economics and Bren School of Environmental Science and Management,

University of California, Santa Barbara, CA, USA

e-mail: kolstad@econ.ucsb.edu

URL: http://www.ckolstad.org

C. D. Kolstad

Resources for the Future,

Washington, DC, USA

C. D. Kolstad

National Bureau of Economic Research, Cambridge, MA, USA 


\section{Background}

There are currently several proposals being considered in the US Congress for a national greenhouse gas policy in the United States, and legislation may be enacted under the Obama Administration. Although there are proposals for a national tax on carbon, most proposed policies rely on a national cap and trade program for limiting and reducing carbon emissions. Like a carbon tax, a cap and trade program for greenhouse gas emissions has the effect of inducing a price on carbon; this means that for the first time in the US a price will be placed on each ton of $\mathrm{CO}_{2}$ emitted. That price per unit of $\mathrm{CO}_{2}$ emitted will ultimately be paid by consumers, shareholders, and workers. Even though an electric utility may write a big check to the government to buy emissions allowances, they may be able to pass that cost on to electricity consumers. And some consumers may be firms which in turn may or may not be able to pass costs on. How these ultimate costs are distributed among these groups and among income classes is a great concern to policymakers and the general public. ${ }^{1}$

Companies facing regulations on greenhouse gas emissions take costly steps to reduce their emissions levels, but the burden is ultimately borne by consumers, workers, or shareholders in the firm. ${ }^{2}$ The costs of compliance are passed on through changes in consumer prices, stock returns, wages, and other returns to factors of production. While an emissions reduction can be achieved in many ways, each method has different costs and consequences. In the case of an emissions tax, emitters obviously face the additional cost associated with the payment of the tax. Of course, this is not a net cost to society since the cost of a tax payment is exactly equal to the gain to the government. If a permit is initially auctioned by the government, the same transfer occurs. ${ }^{3}$ There may, in addition, be costs or inefficiencies generated by the interaction of the tax or permit payment with other taxes, such as an income tax (Goulder et al. 1997).

In this paper we use 2003 consumption data, emissions factors and 1997 data on the structure of the US economy to calculate how a price on carbon is ultimately distributed across income groups. Our estimates are admittedly first order; we assume all costs are passed on to consumers, with workers and capital owners bearing none of the costs. Furthermore, we only calculate the direct burden of the price on carbon, not taking into account consumer and firm response to a higher carbon price in terms of reductions in carbon emissions. Finally, we do not examine the incidence of the benefit of a price on carbon, in terms of the benefits of a marginal reduction in climate change.

Our aim is to obtain a first-order estimate of the extent to which a price on carbon is progressive or regressive by examining consumption patterns and associated emissions for different parts of the income distribution. In what follows, we focus on a carbon tax (actually, a tax on emissions of carbon dioxide), noting that a fully auctioned emissions trading program (with a correctly chosen quota) would generate the same results, albeit through a different mechanism.

Our results suggest that the burden as a percent of annual income is much higher among lower income groups than higher income groups. The policy is less regressive when considering the burden as a percentage of lifetime income, proxied by current expenditures

\footnotetext{
1 In addition to the distribution across income groups, there may be variation in the spatial distribution of costs and benefits (Burtraw et al. 2008).

2 This is true regardless of statutory incidence; that is, the costs of reducing emissions are ultimately passed on, regardless of the point of compliance.

3 In the case of a grandfathered cap-and-trade program, scarcity rents are created, which can actually benefit shareholders. The distributional impact of a cap-and-trade program depends critically on the allocation method (i.e. auctioning vs. grandfathering). See Parry (2004).
} 
(Poterba 1989). However, when accounting for systematic differences in household sizes across income groups using equivalence scales ${ }^{4}$ (see, for example, Citro and Michael 1995), we find that a price on carbon becomes more regressive. We then suggest ways in which the regressive nature of a carbon tax may be ameliorated by pairing it with a reduction in other taxes.

We are not the first to study the incidence of a price on carbon, and previous studies have generally found that carbon taxes and tradable emissions permits are regressive. Metcalf (1999) studies the incidence of green tax reforms, including a carbon tax. Using householdlevel Consumer Expenditure Survey data and input-output accounts, he finds that a carbon tax is regressive, but targeted tax cuts can make the policy distributionally neutral. Parry (2004) uses an analytical model to show that a cap-and-trade program for carbon emissions is regressive. Furthermore, he argues that even if the poor do not have large budget shares for carbon-intensive goods a cap-and-trade program with grandfathered permits can be quite regressive. In a recent paper, Hassett et al. (2009) show that it is fuel and electricity use that drives the regressivity of a carbon tax..$^{5}$

Our study differs from previous literature in several ways. First, we provide estimates of which sectors will likely see the largest percentage increases in cost. Second, we illustrate how consumption differences across income groups drive the regressivity of the policy. Third, in addition to providing household-level consumption and incidence estimates, we show that using equivalence scales and per-capita emissions leads to higher calculated levels of regressivity. Finally, we show how the degree of regressivity varies with the breadth of the tax as well as the measure of income used in the calculations. We calculate the incidence of a broad $\mathrm{CO}_{2}$ price, a price on $\mathrm{CO}_{2}$ for direct energy consumption, and price on all greenhouse gas emissions $\left(\mathrm{CO}_{2}\right.$-equivalent).

\section{Consumption and Emissions Data}

The economic incidence of a tax refers to how the ultimate net costs are distributed in an economy, usually referring to how different income groups are impacted. The distribution of costs and benefits determines the winners and losers from environmental policy. A progressive policy places a larger burden, as a percentage of wealth or income, on richer households, while a regressive policy places larger percentage burdens on poorer groups. Fullerton (2009) discusses six ways environmental policies may have distributional impacts; forward cost-shifting is one of the major drivers of the incidence of environmental policy.

To completely capture the incidence of a price on carbon, we would want to take into account carbon-reducing abatement activities and behavioral changes in examining the extent to which consumers or factors of production bear the cost of the tax. ${ }^{6}$ We would also want to

\footnotetext{
4 Because there are economies of scale in household consumption, household-level analysis may understate the regressivity because wealthier households are larger, on average, than poorer ones. For example, a household with three people does not need three times as much space and electricity as a household with one person. Equivalence scales attempt to account for the nonlinear relationship between household size and needs. This methodology is discussed in greater detail in Sect. 3.

5 The Hassett et al. (2009) paper presents some results which are similar to ours. Their analysis and our analysis were developed apparently independently of each other.

6 Metcalf et al. (2008) use a calibrated model to estimate the incidence of alternative greenhouse gas policies under various assumptions about forward and backward shifting. Their results depend on various factors, including the breadth of the tax, whether other countries act, and short- vs. long-run effects. Other studies taking a similar approach include Shammin and Bullard (2009) for the US, and a number of non-US applications, Kerkhof et al. (2008), Wier et al. (2005) and Labandeira and Labeaga (1999).
} 
estimate the incidence of those abatement activities and how the government uses or refunds the revenues from the taxes or permits. A general equilibrium analysis of the issue would also take into account the changes in relative prices in the economy induced by the tax or costly permits.

A much more modest approach would fix economic activities at their current level and apply a price of carbon, assuming that there is no behavioral or secondary price response in the economy-the carbon price is passed through in its entirety to consumers and consumers do not adjust behavior. Such an analysis will overstate the burden on consumers since in actuality factors of production will bear some of the cost and, further, a higher price of carbon will induce actions to reduce carbon consumption and thus the household's burden. However, modeling behavioral responses and all general equilibrium adjustments would require heroic assumptions about the structure of the economy and price response by income groups for each consumption good in the analysis. Instead, we remain agnostic about where, and to what extent, such adjustments will occur, recognizing that our estimates are likely an upper bound on the regressivity of an actual policy. Our results would be most valid if commodity demands were inelastic, or if all industries use inputs in fixed proportions, because this would not lead to changes in relative factor demands and prices.

In our analysis, we examine the effects of a price of $\$ 15$ per ton of carbon dioxide, equivalent to approximately $\$ 55$ per ton of carbon. ${ }^{7}$ Although there is a great deal of uncertainty regarding what price of carbon may emerge from the current policy debate in the US, this figure is in the range of the allowance prices estimated by the EPA for the Waxman-Markey proposal (Environmental Protection Agency 2009). It should also be noted that, in our analysis, the relative burdens across income groups are independent of our choice of a price.

We begin with data from the 2003 Consumer Expenditure Survey (CES) from the Bureau of Labor Statistics. The CES provides annual consumption patterns for households in each income quintile in the US for a variety of products and services. For each income group, we can then calculate the average household-level expenditure for shelter, electricity, gasoline, vehicles, food, clothing, insurance, and a host of other goods and services. A breakdown of the per-capita expenditures of some of the goods and services is shown in Table 1. For example, according to the CES, an average household in the lowest income quintile spent roughly $\$ 527$ in 2003 on gasoline and motor oil, which was about $4.8 \%$ of their net annual income, whereas the corresponding percentage for a household in the wealthiest quintile is only $1.7 \%$.

Income measurement in the low end of the distribution is poor in the CES, as students, retirees, and transitionally unemployed people are included in this category. As a result, the households with the lowest income in the CES have, on average, an extremely high expenditure to income ratio. Therefore we do not include households with income less than $\$ 7,500$ in our analysis. ${ }^{8}$ Including these households leads to a more regressive calculation of the incidence of a price on carbon emissions.

To estimate the consumption consequences of a carbon price, we need to look at how that price would ripple through the economy, ultimately being borne by the consumer. For instance, food production requires fuel to run tractors (with associated carbon emissions), but

\footnotetext{
7 The conversion between $\mathrm{CO}_{2}$-equivalent and Carbon-equivalent follows from the ratio of the atomic mass of a carbon dioxide molecule to the atomic mass of a carbon atom (44:12). Therefore, a $\$ 15$ tax per ton of carbon dioxide is equivalent to a tax on carbon of $\$ 55$ per ton.

$8 \$ 7,500$ corresponds to around the 5.8th percentile. To be consistent with other studies using these data, as well as studies of the incidence of other taxes, we do not alter our definitions of income quintiles to account for dropping these households.
} 
Table 1 Selected average household expenditures by income quintile (2003)

\begin{tabular}{|c|c|c|c|c|c|}
\hline & Quintile 1 & Quintile 2 & Quintile 3 & Quintile 4 & Quintile 5 \\
\hline $\begin{array}{l}\text { Mean household } \\
\text { income after tax }\end{array}$ & $\$ 10,879$ & $\$ 19,982$ & $\$ 34,007$ & $\$ 54,546$ & $\$ 110,878$ \\
\hline Income range & $\$ 7,500-\$ 14,761$ & $\$ 14,762-\$ 28,594$ & $\$ 28,595-\$ 47,801$ & $\$ 47,802-\$ 77,670$ & $>\$ 77,671$ \\
\hline $\begin{array}{l}\text { Mean number } \\
\text { persons/household }\end{array}$ & 1.8 & 2.3 & 2.6 & 2.9 & 3.1 \\
\hline \multicolumn{6}{|c|}{ Mean household expenditures } \\
\hline Food and alcohol & 2,708 & 3,534 & 4,635 & 5,943 & 8,172 \\
\hline Shelter & 4,613 & 8,570 & 14,049 & 17,800 & 35,486 \\
\hline Natural gas & 259 & 258 & 308 & 409 & 567 \\
\hline Electricity & 620 & 761 & 912 & 1,031 & 1,306 \\
\hline Fuel oil and other fuel & 60 & 71 & 92 & 85 & 151 \\
\hline Telephone services & 506 & 635 & 833 & 1,020 & 1,342 \\
\hline $\begin{array}{l}\text { Water and other } \\
\text { public services }\end{array}$ & 177 & 223 & 295 & 362 & 495 \\
\hline $\begin{array}{l}\text { Household operations, } \\
\text { supplies, } \\
\text { furnishings, } \\
\text { equipment and } \\
\text { apparel }\end{array}$ & 1,440 & 2,076 & 2,907 & 4,223 & 7,648 \\
\hline $\begin{array}{l}\text { Transportation and } \\
\text { vehicle exp. }\end{array}$ & 1,823 & 3,306 & 5,020 & 7,874 & 10,955 \\
\hline Gasoline and motor oil & 527 & 861 & 1,223 & 1,574 & 1,940 \\
\hline Healthcare & 1,500 & 1,723 & 2,176 & 2,388 & 3,264 \\
\hline Other expenditures & 1,597 & 2,609 & 4,230 & 6,196 & 10,940 \\
\hline $\begin{array}{l}\text { Total household } \\
\text { expenditures }\end{array}$ & 15,829 & 24,626 & 36,679 & 48,905 & 82,266 \\
\hline
\end{tabular}

Source: Consumer Expenditure Survey (2003). The households with the lowest income levels $(<\$ 7,500)$ are dropped from the lowest quintile for reasons described in the text. Figures are annual household expenditures in 2003 dollars. The less emissions-intensive consumption categories were aggregated here for exposition only; all subcategories were used in the estimates produced in this paper

it also requires fertilizer, for which carbon was emitted during its production. This suggests the use of an input-output approach.

The standard input-output tables for the US, produced by the US Bureau of Economic Analysis (BEA), divide the economy into a large number of industrial sectors. The IO table for a particular year indicates for each sector $j$, how much was purchased from each of the other sectors $i=1,2, \ldots, n$ to produce $\$ 1$ of output for sector $j$. It is thus a straightforward calculation to translate a vector of final demands in these industrial categories into total production in each of the categories, satisfying both final demand and intermediate demand. This same technique can be used to calculate how a tax on direct carbon emissions in each sector will ripple through the economy to increase the price of final consumption for the sector, assuming no steps are taken to substitute away from carbon intensive goods.

More formally, let $A$ be a $n \times n$ input-output matrix, where the coefficients $a_{i j}$ represent the inputs (in dollars) from sector $j$ necessary to produce $\$ 1$ worth of output for sector $i$. Let $c$ be a vector of final demands for goods in each industry (in dollars), and let $x$ be a vector of total output (in dollars) for the various sectors of the economy. Leontief (1986) formulated this input-output model such that 


$$
A x+c=x \Leftrightarrow x=(I-A)^{-1} c
$$

where $I$ is the identity matrix. ${ }^{9}$

A straightforward use of this traditional input output model is to calculate the emissions associated with production of final consumption goods, accounting for emissions of all primary and intermediate processes necessary to produce final goods (Leontief 1970; Hendrickson et al. 2006). Let $g$ be a vector with the jth element equal to the greenhouse gas emissions (in $\mathrm{CO}_{2}$-equivalent) per $\$ 1$ of output for that sector. For a consumption vector $c$ (in dollars), the resulting total emissions e (a scalar) are then given by

$$
e=g^{\prime} x=g^{\prime}(I-A)^{-1} c .
$$

This method essentially traces emissions through an economy and provides us with estimates of emissions attributable to the consumption of final goods. Now if a tax of $\tau$ dollars per ton of emissions of $\mathrm{CO}_{2}$ (equivalent) were levied, the total tax paid, associated with a consumption vector $c$, would be $\tau e$.

The input-output matrix for the US is regularly compiled and published by the US Department of Commerce, Bureau of Economic Analysis (BEA). The vector of emissions factors, $\mathrm{g}$, is not as readily available, though can be estimated from available data. Researchers at Carnegie-Mellon University (Hendrickson et al. 2006) have estimated these emissions factors and developed an easily used version of the 1997 US input output tables to allow the tracing of greenhouse gas emissions throughout the economy. ${ }^{10}$

Using the Carnegie Mellon version of the US input-output model (the "CMU Model"), we obtain the amount of emissions (both $\mathrm{CO}_{2}$ and all emissions in terms of $\mathrm{CO}_{2}$-equivalent) associated with each of the 491 sectors of input-output accounts. ${ }^{11}$ Table 2 shows the top 20 sectors in terms of $\mathrm{CO}_{2}$ emissions. Assuming a $\$ 15 \mathrm{CO}_{2}$ price in 2009 , the final column shows the percent cost increase for that sector implied by the model. For $\$ 1$ million in purchases, the top emitting sector is lime manufacturing, which is responsible for 9,840 tonnes $\mathrm{CO}_{2}$. The second-highest emitter is sector 221100, Power Generation and Supply, emitting 7,455 tonnes $\mathrm{CO}_{2}$. Considering the large number of sectors in the economy, there are remarkably few sectors that see substantial cost increases (though what constitutes substantial is a subjective judgment). What is relevant to these specific industries is who ultimately bears the burden: consumers, workers or owners.

Then, using data from the BEA, we match sectors of the IO model to the Personal Consumption Expenditure (PCE) categories, which are then comparable to the categories in the CES version developed by the National Bureau of Economic Research (NBER) and which are used in the analysis. ${ }^{12}$

In practice, for any product category, the CMU model tells us how many tons of greenhouse gases are emitted to create $\$ 1$ Million worth of output. Because the process is linear,

\footnotetext{
9 We assume that $(I-A)$ is invertible; in practice, this assumption generally holds true.

10 The CMU model (the Economic Input Output Life Cycle Assessment (EIO LCA) model) is available online at http://www.eiolca.net/about.html.

11 Because consumption data were from (2003), we adjusted expenditures using the Consumer Price Index (CPI) to make prices compatible with 1997 conditions. Because energy prices have increased more than the average price levels, we apply specific deflators for consumption category. This was only to done to get emissions factors for consumption goods; all consumption figures are in 2003 dollars.

12 The NBER CES extracts, available online, are condensed to 109 categories (including income sources) of the CES. This allows the categories to be more comparable to the PCE categories.
} 
Table 2 Sector-level emissions

\begin{tabular}{|c|c|c|c|c|c|}
\hline & Sector & Sector description & $\begin{array}{l}\text { Annual } \mathrm{CO}_{2} \\
\text { emissions }(\mathrm{g} / \$)\end{array}$ & $\begin{array}{l}\text { Annual } \mathrm{CO}_{2} \mathrm{e} \\
\text { emissions }(\mathrm{g} / \$)\end{array}$ & $\begin{array}{l}\text { Cost increase } \\
(\%)\end{array}$ \\
\hline 1 & 327410 & Lime manufacturing & 9,840 & 10,064 & 14.8 \\
\hline 2 & 221100 & $\begin{array}{l}\text { Power generation and } \\
\text { supply }\end{array}$ & 7,455 & 7,827 & 11.2 \\
\hline 3 & 327310 & Cement manufacturing & 5,554 & 5,680 & 8.3 \\
\hline 4 & 325311 & $\begin{array}{l}\text { Nitrogenous fertilizer } \\
\text { manufacturing }\end{array}$ & 4,435 & 9,393 & 6.7 \\
\hline 5 & 325312 & $\begin{array}{l}\text { Phosphatic fertilizer } \\
\text { manufacturing }\end{array}$ & 3,660 & 4,197 & 5.5 \\
\hline 6 & S00202 & $\begin{array}{l}\text { State and local govt } \\
\text { electric utililites }\end{array}$ & 3,191 & 3,429 & 4.8 \\
\hline 7 & 324191 & $\begin{array}{l}\text { Petroleum lubricating oil } \\
\text { and grease man. }\end{array}$ & 2,751 & 2,982 & 4.1 \\
\hline 8 & 325120 & $\begin{array}{l}\text { Industrial gas } \\
\text { manufacturing }\end{array}$ & 2,676 & 7,134 & 4.0 \\
\hline 9 & 331312 & $\begin{array}{l}\text { Primary aluminum } \\
\text { production }\end{array}$ & 2,639 & 4,249 & 4.0 \\
\hline 10 & 325221 & $\begin{array}{l}\text { Cellulosic organic fiber } \\
\text { manufacturing }\end{array}$ & 2,460 & 2,579 & 3.7 \\
\hline 11 & 331311 & Alumina refining & 2,385 & 2,587 & 3.6 \\
\hline 12 & 331112 & $\begin{array}{l}\text { Ferroalloy and related } \\
\text { product manuf. }\end{array}$ & 2,296 & 2,475 & 3.4 \\
\hline 13 & 325130 & $\begin{array}{l}\text { Synthetic dye and } \\
\text { pigment manuf. }\end{array}$ & 2,154 & 2,266 & 3.2 \\
\hline 14 & 212210 & Iron ore mining & 2,050 & 2,199 & 3.1 \\
\hline 15 & 212390 & $\begin{array}{l}\text { Other nonmetallic } \\
\text { mineral mining }\end{array}$ & 1,901 & 2,013 & 2.9 \\
\hline 16 & 331111 & Iron and steel mills & 1,811 & 2,050 & 2.7 \\
\hline 17 & 311221 & Wet corn milling & 1,774 & 3,362 & 2.7 \\
\hline 18 & 486000 & Pipeline transportation & 1,565 & 2,989 & 2.3 \\
\hline 19 & 484000 & Truck transportation & 1,498 & 1,580 & 2.2 \\
\hline 20 & 325314 & $\begin{array}{l}\text { Fertilizer, mixing only, } \\
\text { manufacturing }\end{array}$ & 1,498 & 2,348 & 2.2 \\
\hline
\end{tabular}

Note: Emissions estimates from Carnegie Mellon University Green Design Institute's EIO-LCA model based on 1997 structure of economy. Emissions include direct and indirect emissions attributable to sales (2009 \$) from that sector. An emission rate of $\mathrm{g} / \$$ is equivalent to tones per million $\$$. The cost increase is computed assuming a $\$ 15$ charge per ton of $\mathrm{CO}_{2}$ emissions

we can then calculate the number of tons of $\mathrm{CO}_{2}$ and total greenhouse gases (in terms of $\mathrm{CO}_{2}$-equivalent) that were emitted so that an average consumer in each income quintile could purchase his or her bundle of goods and services. ${ }^{13}$ It is then a straightforward calculation to

13 Emissions resulting from combustion in motor vehicles and the use of natural gas are not included in the CMU Model, as the model only calculates the greenhouse gases associated with the production and distribution of these goods. We add the emissions from using gasoline and natural gas using the standard EPA estimates, imputed by using the average price for these fuels in 2006 to determine the amount purchased. There is evidence that poorer households drive older, less fuel-efficient cars, which would imply that emissions per gallon of gasoline for these income groups could actually be higher (West and Williams 2004). We assume that each income quintile has similar driving habits and vehicles, though differences across income groups would lead to slightly different incidence estimates. In this case, it would increase the regressivity, though accounting for behavioral responses by income group would lead to a greater decrease in quantity demanded for low-income groups, which would have an offsetting effect. 
Table 3 Estimated 2003 household $\mathrm{CO}_{2}$ emissions by income quintile

\begin{tabular}{|c|c|c|c|c|c|}
\hline & Quintile 1 & Quintile 2 & Quintile 3 & Quintile 4 & Quintile 5 \\
\hline $\begin{array}{l}\text { Household income } \\
\text { range (after taxes) }\end{array}$ & $\$ 7,500-\$ 14,761$ & $\$ 14,762-\$ 28,594$ & $\$ 28,595-\$ 47,801$ & $\$ 47,802-\$ 77,670$ & $>\$ 77,671$ \\
\hline Mean (after tax) income & $\$ 10,879$ & $\$ 19,982$ & $\$ 34,007$ & $\$ 54,546$ & $\$ 110,878$ \\
\hline Mean household size & 1.8 & 2.3 & 2.6 & 2.9 & 3.1 \\
\hline \multicolumn{6}{|c|}{ Mean household emissions (metric tons of $\mathrm{CO}_{2}$ per household) } \\
\hline Food and alcohol & 2.19 & 2.83 & 3.69 & 4.67 & 6.28 \\
\hline Shelter & 1.87 & 3.68 & 6.04 & 7.32 & 14.74 \\
\hline Natural gas & 1.99 & 1.97 & 2.35 & 3.13 & 4.34 \\
\hline Electricity & 7.26 & 8.91 & 10.68 & 12.08 & 15.30 \\
\hline Fuel oil and other fuel & 0.68 & 0.81 & 1.05 & 0.96 & 1.71 \\
\hline Telephone services & 0.06 & 0.07 & 0.09 & 0.11 & 0.15 \\
\hline $\begin{array}{l}\text { Water and other } \\
\text { public services }\end{array}$ & 0.17 & 0.21 & 0.28 & 0.34 & 0.47 \\
\hline $\begin{array}{l}\text { Household operations, } \\
\text { supplies, } \\
\text { furnishings, } \\
\text { equipment and } \\
\text { apparel }\end{array}$ & 0.61 & 0.90 & 1.31 & 1.87 & 3.40 \\
\hline $\begin{array}{l}\text { Transportation and } \\
\text { vehicle expense }\end{array}$ & 0.44 & 0.96 & 1.58 & 2.53 & 3.39 \\
\hline $\begin{array}{l}\text { Gasoline and motor } \\
\text { oil }\end{array}$ & 4.99 & 8.15 & 11.59 & 14.92 & 18.38 \\
\hline Healthcare & 0.29 & 0.33 & 0.42 & 0.42 & 0.62 \\
\hline Other expenditures & 1.16 & 1.66 & 2.38 & 3.65 & 7.21 \\
\hline Total emissions & 21.70 & 30.49 & 41.45 & 51.98 & 75.99 \\
\hline
\end{tabular}

Source: Authors' calculations using Consumer Expenditure Survey (2003) data and the CMU model described above

determine how much the average consumer in each income quintile would pay for a given price on carbon induced by a tax or permit price.

Using this method implies an aggregate level of US $\mathrm{CO}_{2}$ emissions in 2003 to be about $5,298 \mathrm{Tg} \mathrm{CO}$, compared to the EPA's greenhouse gas inventory estimate of 5,953 $\mathrm{Tg} \mathrm{CO}$ (USEPA 2007). ${ }^{14}$ Similarly, we calculate the total greenhouse gas emissions for 2003 to be $6,582 \mathrm{Tg} \mathrm{CO}_{2}$-equivalent, compared to $7,104 \mathrm{Tg} \mathrm{CO}_{2}$-equivalent from the EPA. Considering that the CMU model is calibrated to the 1997 economy, our implied emissions calculation for 2003 is remarkably close to observed data. On a per-capita basis, this implies an 'average' consumer's annual emissions of about 18.2 metric tons of $\mathrm{CO}_{2},{ }^{15}$ compared to estimates of 20.5 by the EPA.

The total household emissions were calculated for each household's consumption bundle by simply adding the emissions for each product in the bundle for that year. Annual average emissions estimates are shown for households in each income quintile in Table 3. As shown in the table, the households from the poorest income quintile consumed goods and services associated with 21.7 metric tons of $\mathrm{CO}_{2}$ in 2003 , while the average household in the top

\footnotetext{
$14 \mathrm{Tg}$ stands for teragram and is equal to $10^{12} \mathrm{~g}$ which is a million metric tons.

15 This is based on a July, 2003 US Census population estimate.
} 
Table 4 Estimated 2003 household $\mathrm{CO}_{2}$-equiv. emissions by income quintile

\begin{tabular}{|c|c|c|c|c|c|}
\hline & Quintile 1 & Quintile 2 & Quintile 3 & Quintile 4 & Quintile 5 \\
\hline $\begin{array}{l}\text { Household income } \\
\text { range (after taxes) }\end{array}$ & $\$ 7,500-\$ 14,761$ & $\$ 14,762-\$ 28,594$ & $\$ 28,595-\$ 47,801$ & $\$ 47,802-\$ 77,670$ & $>\$ 77,671$ \\
\hline $\begin{array}{l}\text { Mean per-capita (after } \\
\text { tax) income }\end{array}$ & $\$ 10,879$ & $\$ 19,982$ & $\$ 34,007$ & $\$ 54,546$ & $\$ 110,878$ \\
\hline Mean household size & 1.8 & 2.3 & 2.6 & 2.9 & 3.1 \\
\hline \multicolumn{6}{|c|}{ Mean household emissions (metric tons of $\mathrm{CO}_{2}$-equivalent per household) } \\
\hline Food and alcohol & 4.64 & 5.92 & 7.67 & 9.55 & 12.56 \\
\hline Shelter & 2.22 & 4.37 & 7.17 & 8.68 & 17.46 \\
\hline Natural gas & 2.43 & 2.42 & 2.88 & 3.83 & 5.32 \\
\hline Electricity & 7.62 & 9.36 & 11.22 & 12.69 & 16.06 \\
\hline Fuel oil and other fuel & 0.75 & 0.90 & 1.17 & 1.07 & 1.91 \\
\hline Telephone services & 0.06 & 0.08 & 0.11 & 0.13 & 0.17 \\
\hline $\begin{array}{l}\text { Water and other } \\
\text { public services }\end{array}$ & 1.16 & 1.45 & 1.92 & 2.36 & 3.23 \\
\hline $\begin{array}{l}\text { Household operations, } \\
\text { supplies, } \\
\text { furnishings, } \\
\text { equipment and } \\
\text { apparel }\end{array}$ & 0.76 & 0.93 & 1.37 & 1.84 & 3.29 \\
\hline $\begin{array}{l}\text { Transportation and } \\
\text { vehicle expense }\end{array}$ & 0.53 & 1.13 & 1.86 & 2.99 & 4.01 \\
\hline Gasoline and motor oil & 5.73 & 9.36 & 13.30 & 17.12 & 21.11 \\
\hline Healthcare & 0.36 & 0.41 & 0.52 & 0.52 & 0.77 \\
\hline Other expenditures & 1.21 & 1.93 & 2.74 & 4.17 & 8.09 \\
\hline Total emissions & 27.47 & 38.26 & 51.92 & 64.95 & 93.96 \\
\hline
\end{tabular}

Source: Authors' calculations using Consumer Expenditure Survey (2003) data and the CMU model described above

quintile was responsible for about emissions of 76 tons of $\mathrm{CO}_{2}$. Similarly, Table 4 shows the breakdown of $\mathrm{CO}_{2}$-equivalent emissions by income group.

As shown in Tables 3 and 4, the most carbon-relevant sectors are fossil-fuel intensive; gasoline, electricity, natural gas and food are the goods purchased by consumers with the highest associated emissions. These tables could also be interpreted in terms of carbon intensity of consumption. Households in the lowest income quintile are responsible for an average of 1.99 metric tons of $\mathrm{CO} 2$ emissions per $\$ 1,000$ worth of income, whereas households in the highest quintile are responsible for about 0.69 metric tons of emissions per $\$ 1,000$ in income. The upper quintile is nearly three times more efficient than the bottom quintile, but the top quintile accounts for roughly $35 \%$ of aggregate emissions. In the next section we use these data to calculate the incidence of a price on carbon.

\section{The Incidence of a Price on Carbon}

Using emissions calculations from the previous section, we calculate the burden of a price on carbon emissions for each household in the CES. For a tax of $\$ 15$ per ton of $\mathrm{CO}_{2}$ (based on the emissions estimates in Table 3), an average household in the lowest income quintile would pay around $\$ 325$ per year, while an average household in the wealthiest quintile would 
pay $\$ 1,140$ annually. Although wealthier households would pay more in absolute terms, as a percentage of annual income, lower income groups bear a disproportionate share of the burden. The poorest quintile's burden (as a share of annual income) is 3.2 times that of the wealthiest quintile's.

When looking at the extremes in the household income distribution the regressive nature of a price on carbon is even more pronounced. The burden as a share of annual income for the lowest income group $(\$ 7,500-9,999)$ is almost four times higher than the burden-to-income ratio for the highest income group in the data $(\$ 200,000-250,000)$. This is seen graphically in Fig. 1, where the percentage of household expenditures on a price on carbon is plotted against income groups.

There is a debate among economists as to whether current income or lifetime income should be used in the calculation of the incidence of a policy. Because annual income is volatile, and because it tends to increase and then decrease with age, a person's annual income may not be a good proxy for their permanent income over their lifetime. However, lifetime income is far more difficult to measure. ${ }^{16}$ Current expenditures can be used as a proxy for lifetime income if consumption is relatively smooth over a person's lifespan (Poterba 1989; Metcalf 1999). ${ }^{17}$ We use current expenditures as our measure of lifetime income, though some authors find that using current expenditures as a proxy for lifetime income exaggerates regressivity at lower income levels (Caspersen and Metcalf 1994). When comparing the burden as a percentage of annual expenditures, a household's burden in the lowest income quintile is about 1.4 times that of the highest quintile (Fig. 1).

There is a systematic difference in average household size across income groups, which can be seen in the CES summary statistics in Table 1. Households in the lowest income quintile have an average of 1.8 persons, whereas households in the top quintile have, on average, 3.1 persons. Since wealthy households are larger, on average, this inflates the relative income of the poorer households, all other things being equal (Cutler and Katz 1992). Thus, using household level data for emissions and income may lead to a lower estimate of regressivity than if one accounts for these differences. However, adjusting for this using household size will distort the results since there are economies of scale in providing household services (two can leave cheaper than two households of one). Therefore, in addition to household income (annual and lifetime), we use equivalence scales to calculate the incidence of a carbon price. Equivalence scales have been used widely (e.g. Cutler and Katz 1992; Fernandez-Villaverde and Krueger 2007), and are meant to account for economies of scale in household consumption. Following Cutler and Katz, we parameterize equivalent persons, $E$, as $E=(A+.4 K)^{.5}$, where $A$ is the number of adults, and $K$ is the number of children. For households with at least two people, we assume that the first two people are adults and the others are children. However, if the number of income-earners in the household exceeds two, we set $A$ equal to the number of income earners. For each household, we then calculate the per-capita burden of a price on carbon as a percent of household income scaled by $E$.

Figure 1 shows the burden-to-income ratios for household annual income, household lifetime income, annual equivalent income, and lifetime equivalent income, by household

\footnotetext{
16 The data used here make measuring lifetime income impossible, so a proxy is used. Fullerton and Rogers (1993) measure lifetime income and classify households accordingly. They find that the bias in regressivity based on annual income is not as severe as suggested by previous researchers. However, their results are based on consumption taxes, not a price on carbon, and the resulting bias in our calculations is unknown.

17 According to the lifetime income hypothesis, consumption is relatively smooth across time because people make contemporaneous consumption decisions based on their lifetime (and not current) income. For example, students may take out loans to support themselves during college because they anticipate earning income after graduating, and workers forgo consumption and save so that they have money for retirement.
} 


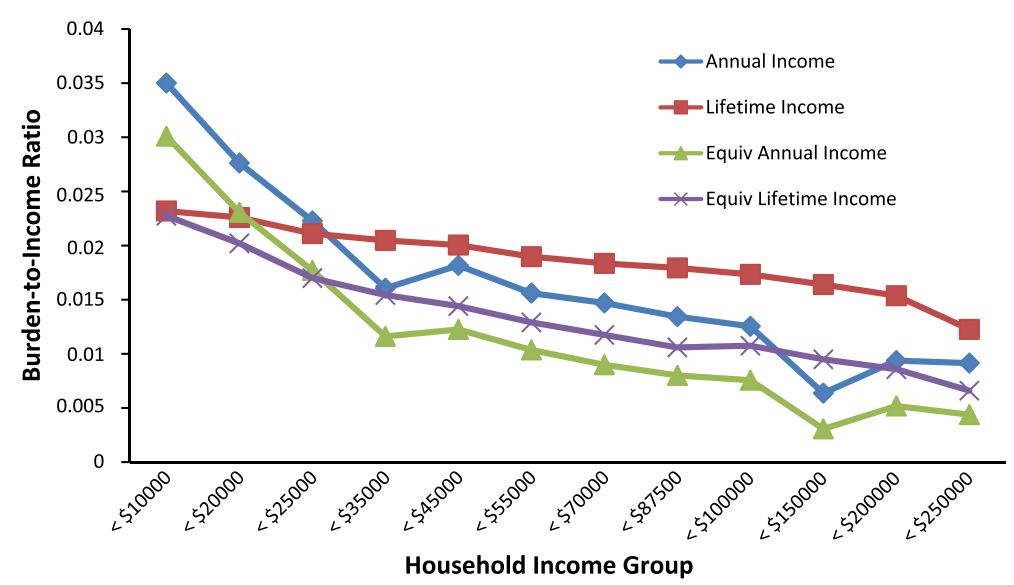

Fig. 1 Broad $\mathrm{CO}_{2}$ Tax Burden by Household Income Group. Note: Assumes $\mathrm{CO}_{2}$ price of $\$ 15 /$ ton. Shows total incidence by income group as a percent of annual net income and current expenditures. Equivalent income measures are described in the text. Authors' calculations using consumption data from the Consumer Expenditure Survey and associated emissions from the Economic Input Output model from Carnegie Mellon University

income group. For a price on all $\mathrm{CO}_{2}$ emissions, the use of equivalent annual income leads to a more regressive calculation than household-level annual income. The per-capita burden-toequivalent-income ratio for the lowest income group (between $\$ 7,500$ and $\$ 9,999$ ) is nearly 7 times greater than for the highest income group (between $\$ 200,000$ and $\$ 250,000$ ). On an equivalent lifetime income basis, the ratio is about 3.5 times higher for the lowest income group.

There are alternative ways of computing equivalence scales, leading to slightly different calculations of regressivity (Citro and Michael 1995). Though the calculations would change slightly, any parameterization with increasing returns would lead to a more regressive calculation of incidence than calculations at the household level. As an alternative, we also present results using the OECD equivalence scales. This parameterization assigns a value of 1 for the first adult, .7 for additional adult, and .5 for each child. For households with at least two people, we again assume that the first two people are adults and the others are children. However, if the number of income-earners in the household exceeds two, we assume that the number of adults equals the number of income earners. The results using this choice of equivalence scales are summarized in Fig. 4 (Appendix). ${ }^{18}$

We then considered a price on all greenhouse gas emissions (in terms of $\mathrm{CO}_{2}$-equivalent). Figure 2 shows the calculations by income group using the four measures of income. Again, the policy is regressive using all measures. Using annual income, the ratio for the lowest income quintile is 3.25 times higher than the highest income quintile, but on a lifetime basis it is only 1.4 times as high. Using equivalent income, the per-capita burdens are about five times higher on an annual basis for the lowest income group than the highest. And on an equivalent lifetime income basis (i.e. equivalent expenditures), the ratio is about twice as large for the lowest quintile. Figure 5 shows the similar results using the OECD equivalence

18 In this case, the per-capita burden-to-equivalent-income ratio for the lowest income group (between $\$ 7,500$ and $\$ 9,999$ ) is over 5 times greater than for the highest income group (between $\$ 200,000$ and $\$ 250,000$ ). On an equivalent lifetime income basis, the ratio is about 2.6 times higher for the lowest income group. 


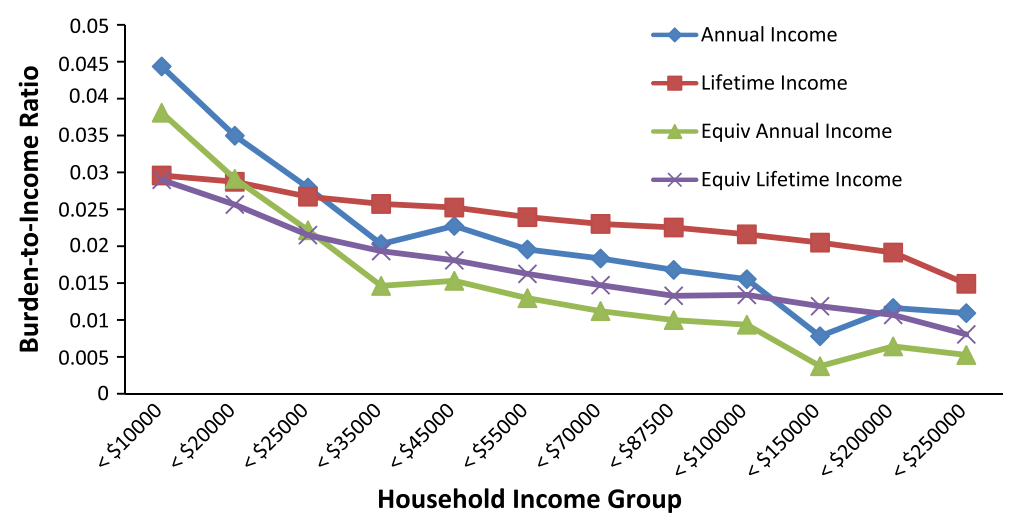

Fig. 2 Broad $\mathrm{CO}_{2}$-Equivalent Tax Burden by Income (\%). Note: Burden to income ratio from a tax on $\mathrm{CO}_{2}$ equivalent (\$15/ton) as a fraction of annual net income and current expenditures. Equivalent income measures are described in the text. Authors' calculations using consumption data from the Consumer Expenditure Survey and associated emissions from the Economic Input Output model from Carnegie Mellon University

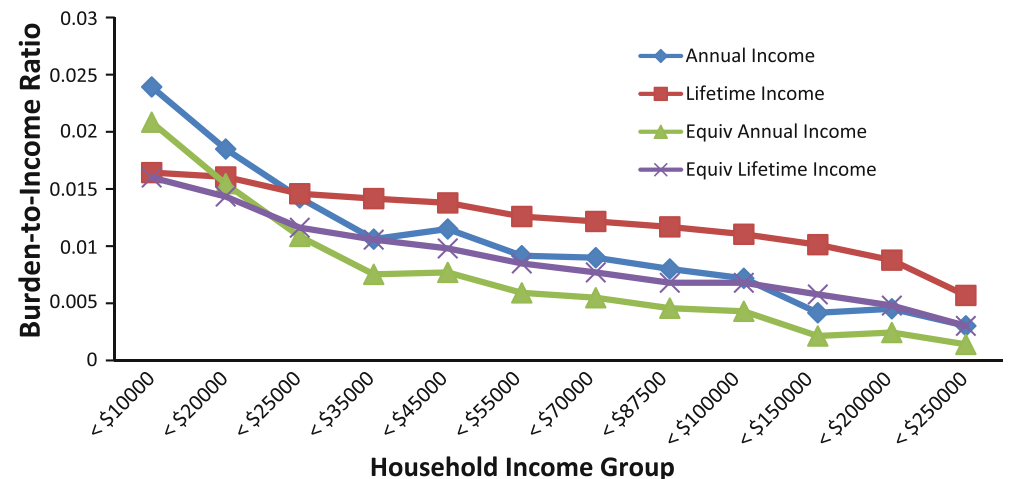

Fig. $3 \mathrm{CO}_{2}$ Tax Only on Consumption of Energy Goods. Note: Burden to income ratio from $\mathrm{CO}_{2}$ price (\$15/ton), as a fraction of annual net income and current expenditures. Equivalent income measures are described in the text. Authors' calculations using consumption data from the Consumer Expenditure Survey and associated emissions from the Economic Input Output model from Carnegie Mellon University

scales. Including all greenhouse gases results in a slightly more regressive policy, which is driven largely by the emissions attributable to food and alcohol consumption. The lowest income group's $\mathrm{CO} 2 \mathrm{e}$ emissions for that consumption group are more than twice their $\mathrm{CO}_{2}$ emissions, whereas it is only $90 \%$ larger for the highest income group.

Finally, we consider a price only on $\mathrm{CO}_{2}$ emissions from consumption of energy goods. The distribution of the burden on consumers from a higher price on gasoline, electricity, natural gas and fuel oil is shown in Fig. $3 .{ }^{19}$ Using household annual income, the ratio for the lowest income quintile is almost four times higher than the highest quintile, and on a lifetime income basis (using expenditures) we calculate that the ratio is about 1.6 times higher. Using equivalent annual income, the per-capita burden is about six times higher for the lowest quintile, and using equivalent lifetime income the per-capita burden is over 2.6 times higher. ${ }^{20}$

19 Figure 6 shows the similar results using the OECD equivalence scales.

20 When comparing households earning between $\$ 7,500$ and $\$ 9,999$ to households earning more than $\$ 250,000$, the ratio for the poorest household is almost fifteen times larger. 
Similar to the findings in Hassett et al. (2009), it appears that the regressivity of the policy is driven largely by direct energy consumption.

A price on carbon, given the assumptions above, would be regressive, but the degree of regressivity depends on the income measure used. On an annual basis, a carbon price is 2-3 times more regressive than on a lifetime basis (i.e. using annual expenditures). When examining the policy on a per-capita basis with equivalence scales, a carbon price is roughly twice as regressive as at the household level. In each case the regressivity is largely driven by direct energy consumption. This finding is consistent with other studies of the household incidence of carbon emission policies. ${ }^{21}$ Furthermore, as discussed briefly in the next section, the overall regressivity of a policy depends critically on how the revenues are used.

\section{Policy Implications}

The regressive nature of pollution control policies is often of real concern to politicians; however, when revenue is being generated, new revenues could be used to benefit those harmed disproportionately by the new policy. Because the price on carbon discussed here would generate substantial revenues for the government, it is important to consider how these revenues might be spent to reduce the regressivity of the policy. As discussed elsewhere in the literature (e.g. Parry et al. 2005), a price on carbon could be made less regressive, or even progressive, by "recycling" the revenue into tax cuts elsewhere in an economy. ${ }^{22}$ This could be achieved by targeting income tax cuts at lower income groups, reducing (or even eliminating) other federal taxes, or by increasing spending on government programs targeted at lower income groups. Here we briefly discuss these options; for a more thorough (partial equilibrium) discussion of a revenue-neutral carbon tax swap, see Metcalf et al. (2008).

To make the carbon emissions policy discussed above distributionally neutral, lump-sum transfers (cash payments that do not alter incentives or behavior) could be used. A more practical alternative would be to reduce the income tax burden for individuals based on their annual income. In practice, the price on carbon here could be made distributionally neutral by directing transfers (or income tax credits) in the amounts of $\$ 119, \$ 112, \$ 105$, and $\$ 76$ to individuals in the first four income quintiles, respectively. ${ }^{23}$ This would place a burden on each household of around $1 \%$ of net annual income (equal to the burden of the highest income group), offsetting the regressive effects of the price on carbon while leaving $\$ 49.6$ Billion in government revenues.

Alternatively, revenues from a price on carbon could be used to finance cuts in other taxes. ${ }^{24}$ The study of the incidence of taxes is a major subfield of public finance, and many

\footnotetext{
21 Other economic studies of carbon taxes (e.g. Metcalf et al. 2008; Wier et al. 2005) generally find that they are regressive, but the degree varies based on the methodology, assumptions, and income basis (annual vs. lifetime). For example, Metcalf et al. (2008) uses 2003 consumption data to estimate the partial equilibrium incidence of a carbon tax. For a $\$ 15$ carbon tax, he finds that an average consumer in the lowest income decile would experience a decrease in disposable income of 3.4\%, whereas the wealthiest income decile's disposable income would decrease by $0.8 \%$. Wier et al. (2005) find that the poorest decile spent $0.8 \%$ of disposable income on the Danish carbon tax, while the wealthiest spent about $0.3 \%$ of their disposable income. For a review of other policies, see Parry et al. (2005).

22 In a recent paper, Boyce and Riddle (2009) examine the state-by-state incidence of a \$25 carbon tax/permit price, $80 \%$ of the revenues of which are rebated to consumers.

23 These are not the only transfers that would achieve distributional neutrality. They are the minimum such transfers.

24 To the extent that the pre-existing taxes are distortionary, under certain conditions this may even lead to an efficiency gain (Goulder et al. 1997).
} 
empirical (and theoretical) studies have focused on the distributional incidence of payroll taxes, value-added taxes ${ }^{25}$, sales taxes, and excise taxes. The literature generally finds these taxes to be regressive, though the degree varies widely due to assumptions about income, the amount of pass-through, and other factors (Fullerton and Metcalf 2002). For example, Poterba (1989) study of the incidence of a gasoline tax finds that the bottom quintile's burden as a percent of current income is 5.3 times as high as that of the highest income quintile's. When calculating the burden as a share of current expenditures, he finds that it is less regressive-about 1.5 times as high. ${ }^{26}$

One candidate for revenue recycling would be to use revenues to finance cuts in the payroll tax. ${ }^{27}$ The payroll tax is regressive. Although part of the burden is statutorily paid by the employer, most studies find that the burden falls almost entirely on workers through reductions in wages (Fullerton and Metcalf 2002). The Federal Insurance Contributions Act (FICA) tax is regressive in its very nature because beyond the Wage Base limit (currently $\$ 102,000$ per year), any additional earnings are untaxed. Therefore the tax, as a percentage of income, effectively declines as income increases beyond that level. ${ }^{28}$ According to Chamberlain and Prante, the average effective tax rate for the payroll tax in 2004 was $2.75 \%$ for the lowest income quintile, $7.11 \%$ for the second, $9.05 \%$ for the third, $9.53 \%$ for the fourth, and $7.79 \%$ for the top quintile. Targeted revenue recycling from a carbon emissions policy could help create a more distributionally neutral payroll tax.

In order to fully analyze how to finance cuts in pre-existing taxes to create a distributionally neutral (or even progressive) bundle of taxes, we would need to analyze the general equilibrium effects of the overall tax system. However, a back-of-the-envelope estimate using the figures from the prior section suggests that the total annual revenues from a price on carbon of $\$ 15$ per ton would equal approximately $\$ 79.2$ Billion. Although this is most likely an upper bound on actual revenues, because of reasons discussed above, a price on carbon could yield substantial government revenues, and careful recycling of these revenues could offset the regressive nature of a national GHG emissions policy.

\section{Conclusions}

We use the Consumer Expenditure Survey and an augmented input-output model of the US economy to determine the extent to which a price on carbon in the United States is regressive. We show that the costs of a price on carbon borne by consumers are regressive by

\footnotetext{
25 The literature on the incidence of a value-added tax (VAT) generally finds that such a policy is regressive. Caspersen and Metcalf (1994) find that a value added tax on food, housing and healthcare is mildly regressive, with the ratio of the median tax liability to income for the lowest income decile equal to 2.3 , and for the highest decile 1.1. When using proxies for lifetime income, the degree of regressivity declines. Because there is no federal VAT in the US, revenues from a carbon tax could not be used to finance reductions in the VAT.

26 West and Williams (2004) also study the incidence of a gasoline tax, but they estimate the elasticity of demand for each income group and find that the tax is less regressive if one accounts for this behavioral response.

27 In fact, Representative John B. Larson of Connecticut has introduced a bill (HR 3416) into the US Congress to tax carbon but to couple this with a revenue neutral reduction in the payroll tax. His proposal involves the carbon tax starting small and gradually increasing over time.

28 However, a Congressional Budget Office study (Congressional Budget Office 2006) argues that the overall social security system is progressive once benefits are factored in. On the other hand, Coronado et al. (2000) show that the progressivity of social security depends critically on the methodology of calculation. When incorporating mortality probabilities that differ by potential lifetime income, they find that social security, overall, is no longer progressive; for a discount rate of $4 \%$, it is even regressive.
} 
nature because polluting goods are mostly energy-intensive and take up a large percentage of a low-income person's budget. The degree of regressivity varies with the breadth of the policy. The incidence of a carbon price applied only to final energy consumption is nearly twice as regressive as a price applied to all $\mathrm{CO}_{2}$ emissions. Furthermore, taking into account differences in household size across income groups and equivalence scales, the per-capita incidence suggests a much more regressive policy than calculations at the household level.

Although we find that the costs of a greenhouse gas pricing policy in the United States to be regressive, a few caveats are in order. The direct burden is only one channel through which a climate policy has distributional effects, and as discussed earlier, there are other factors that determine the overall incidence of a carbon tax or emissions trading system (Fullerton 2009). For example, we do not consider the distribution of the benefits of a greenhouse gas policy. If low income groups have more to gain from a cap-and-trade program or a carbon tax, the 'net' incidence of the policy may actually be progressive; alternatively, if wealthier households have more to gain, the 'net' incidence may be even more regressive.

There are several other caveats from our analysis. First, producers were assumed not to change production choices, costs were assumed to be fully passed through to consumers, and consumers are assumed to be unresponsive to increased product prices. Other researchers have found that low-income consumers are more responsive to price increases of polluting goods such as gasoline (West and Williams 2004). Depending on the price elasticity of demand for other energy-intensive products, this would be expected to reduce the regressivity of a price on carbon. ${ }^{29}$ Second, some of the costs may be borne by factors of production, such as labor, capital or natural resource owners (Fullerton and Heutel 2007). Environmental regulations may change real wages and returns to capital, which would change the optimal production inputs (and hence emissions) for various sectors, and the distribution of these costs across income groups affects the overall incidence of a price on carbon. Third, while we consider a broad price on carbon that takes into account all emissions, in practice a carbon tax or emissions trading system may have exemptions for emissions from some industries due to political considerations or high monitoring costs.

The regressive nature of the costs of a price on carbon could be alleviated (or eliminated) by carefully recycling revenues. This could be done by targeted transfers, financing cuts in regressive payroll or excise taxes, targeting income tax cuts at lower income groups, or by increasing spending on government programs targeted at lower income groups. ${ }^{30}$

Acknowledgements We would like to thank Don Fullerton, Josh Graff-Zivin, Matthew Kahn, Gilbert Metcalf, Peter Reiss, Margaret Walls, seminar and conference participants, and anonymous referees for comments. We are responsible for all errors. Grainger acknowledges financial support from the National Science Foundation, Grant No. 0114437.

Open Access This article is distributed under the terms of the Creative Commons Attribution Noncommercial License which permits any noncommercial use, distribution, and reproduction in any medium, provided the original author(s) and source are credited.

\footnotetext{
29 Because we are not modeling the behavioral response for each commodity group, our estimates are likely an upper bound on the incidence of a price on carbon.

30 In an analysis of the Waxman-Markey bill passed by the US House in June 2009, the Congressional Budget Office calculated that the spending programs in the bill offset virtually all of the regressive aspects of the cap and trade system, and furthermore reduced the average household cost from $1.0 \%$ of household income to $0.2 \%$ (Congressional Budget Office 2006).
} 


\section{Appendix: Alternative Specification of Equivalence Scales}

In each figure below, the burden-to-income ratio is plotted for annual (household) income, lifetime income (household expenditures), and alternative measures of equivalent annual and lifetime income. The OECD equivalence scales are used here, which assigns a value of 1 for the first adult, .7 for each additional adult, and .5 for each child.

See Figs. 4, 5 and 6.

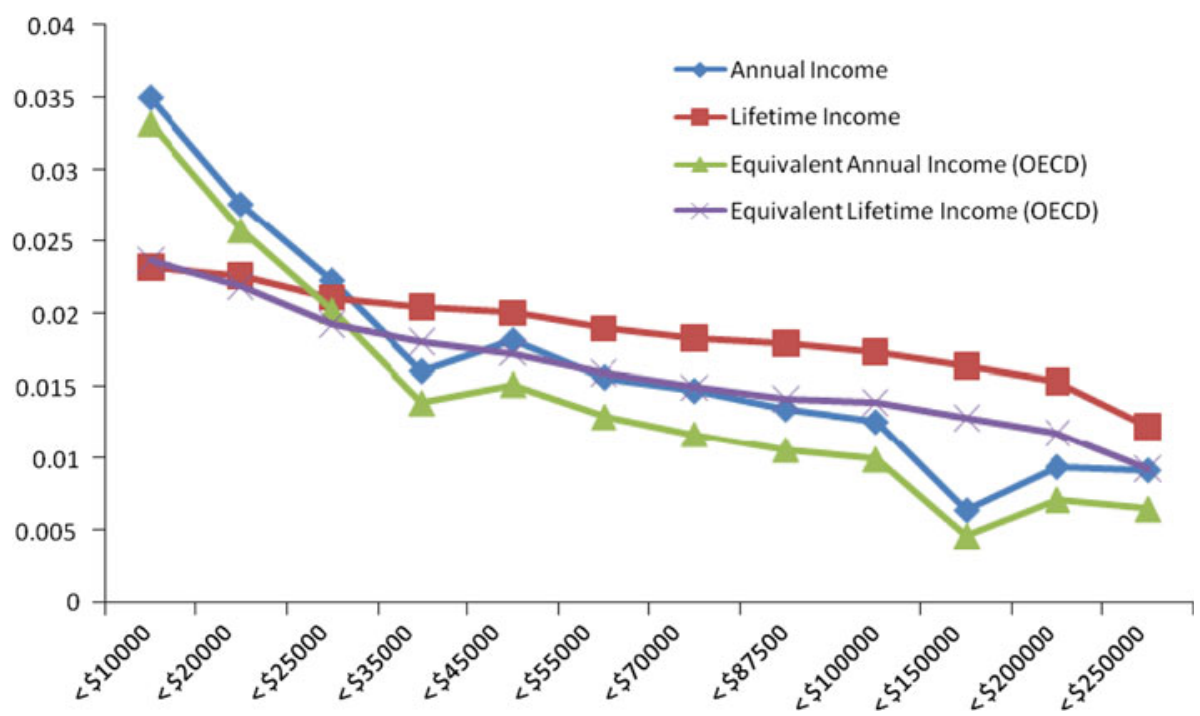

Fig. $4 \quad \mathrm{CO}_{2}$ Tax incidence (OECD equivalence scales)

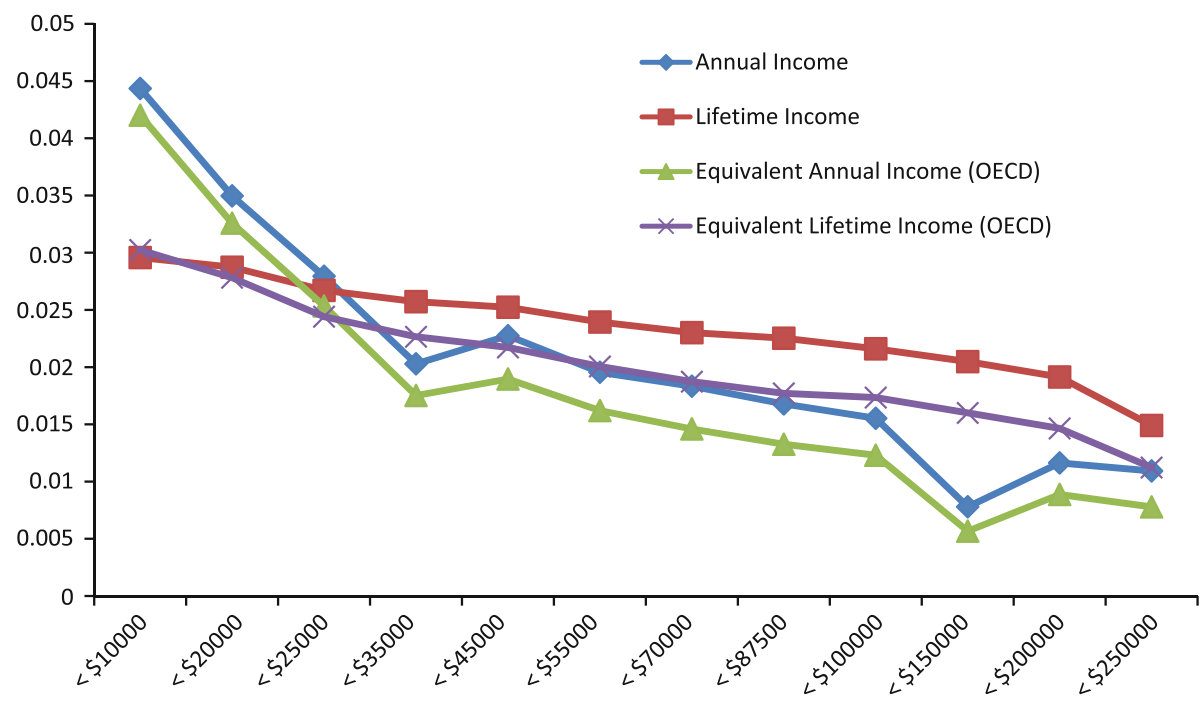

Fig. 5 Greenhouse gas tax incidence (OECD equivalence scales) 


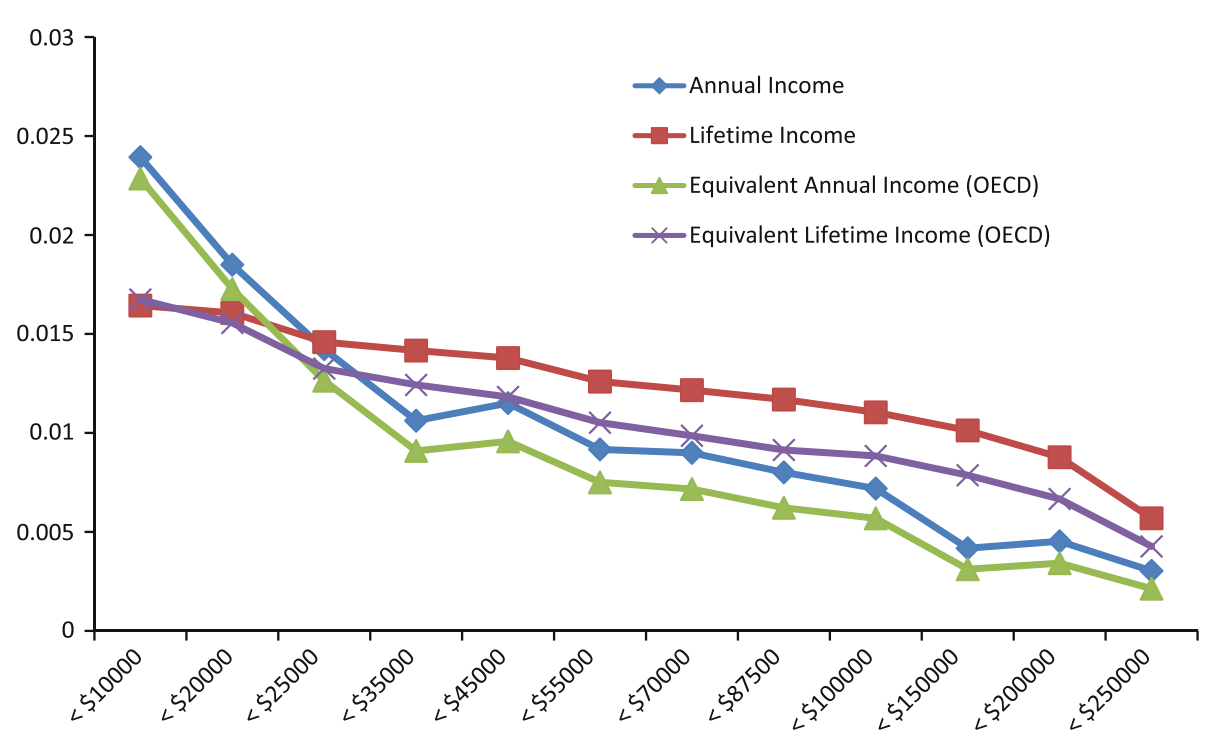

Fig. $6 \mathrm{CO}_{2}$ tax on direct energy consumption (OECD equivalence scales)

\section{References}

Andrew C, Gerald P (2007) Who pays taxes and who receives government spending? An analysis of federal, state and local tax and spending distributions, 1991-2004. http://www.taxfoundation.org/files/wp1.pdf.

Boyce JK, Riddle ME (2009) Cap and dividend: a state-by-state analysis, Political Economy Research Institute, University of Massachusetts, Amherst. http://e3network.org/papers/CAP_DIVIDEND_states.pdf

Carnegie Mellon University Green Design Institute (2008) Economic Input-Output Life Cycle Assessment (EIO-LCA) model [Internet], Available from: http://www.eiolca.net/. Accessed 19 Jul 2008

Caspersen Erik, Metcalf Gilbert E (1994) Is a value added tax regressive? Annual versus lifetime incidence measures. Natl Tax J 47:731-746

Citro CF, Michael RT (1995) Measuring poverty: a new approach. National Academy Press, Washington

Congressional Budget Office (CBO), Letter from David Elmendorf (CBO Director) to Rep. David Camp (House Ways and Means) dated 19 June 2009. http://www.cbo.gov/ftpdocs/103xx/doc10327/ 06-19-CapAndTradeCosts.pdf

Consumer Expenditure Survey (2006) Microdata Extracts, NBER. Available http://www.nber.org/data/ces_ cbo.html

Cutler DM, Katz LF (1992) Rising inequality? Changes in the distribution of income and consumption in the 1980's. Am Econ Rev 82(2)

Dallas B, Rich S, Margaret W (2008) The incidence of US climate policy: where you stand depends on where you sit. Discussion Paper 08-28, Resources for the Future, Washington, DC

Don F, Metcalf GE (2002) Tax incidence handbook of public economics. In: Auerbach AJ, Feldstein M (ed) Elsvier, Amsterdam, pp 1788-1839

Environmental Protection Agency (2009) EPA Economic Analysis of the American Clean Energy and Security Act of 2009. http://energycommerce.house.gov/Press_111/20090623/hr2454_epasummary.pdf. Accessed 31 Aug 2009

Fernandez-Villaverde J, Krueger D (2007) Consumption over the life cycle: facts from CEX data. Rev Econ Stat 89(3):552-565

Fullerton D (2009) Distributional effects of environmental and energy policy: an introduction. In: Fullerton DDistributional effects of environmental and energy policy. Ashgate, Aldershot

Fullerton D, Heutel G (2007) The general equilibrium incidence of environmental taxes. J Public Econ 91: 571-591

Fullerton D, Rogers DL (1993) Who bears the lifetime tax burden?. Brookings Institution, Washington

Goulder LH, Parry IWH, Burtraw D (1997) Revenue-raising versus other approaches to environmental protection: the critical significance of preexisting tax distortions. Rand J Econ 28:708-731 
Hassett KA, Aparna M, Metcalf GE (2009) The incidence of a US carbon tax: a lifetime and regional analysis. Energy J 30(2)

Hendrickson CT, Lave LB, Matthews HS (2006) Environmental life cycle assessment of goods and services: an input-output approach. Resources for the Future Press, Washington

Kerkhof AC, Moll HC, Drissen E, Wilting HC (2008) Taxation of multiple greenhouse gases and the effects on income distribution: a case study of the Netherlands. Ecol Econ 67:318-326.

Labandeira X, Labeaga JM (1999) Combining input-output analysis and micro-simulation to assess the effects of carbon taxation on Spanish households. Fisc Stud 20:305-320

Leontief W (1970) Environmental repercussions and the economic structure: an input-output approach. Rev Econ Stat 52(3):262-271

Leontief W (1986) Input-output economics. 2. Oxford University Press, New York

Lynn CJ, Don F, Thomas G (2000) The Progressivity of Social Security Working Paper 7520, National Bureau of Economic Research, Cambridge, MA

Metcalf GE (1999) A distributional analysis of green tax reforms. Natl Tax J 52:665-681

Metcalf GE (2009) A proposal for a US carbon tax swap: an equitable tax reform to address global climate change. Rev Environ Econ Policy 3:63-83

Metcalf GE, Sergey P, Reilly JM, Jacoby HD, Jennifer H (2008) Analysis of US greenhouse gas tax proposals. MIT Joint Program on the Science and Policy of Global Change Report 160

Morgenstern RD, Ho M, Shih S-S, Zhang X (2004) The near-term impacts of carbon mitigation policies on manufacturing industries. Energy Policy 32:1825-1841

Paltsev S, Reilly J, Jacoby H, Gurgel A, Metcalf G, Sokolov A, Holak J (2007) Assessment of US cap-and-trade proposals. MIT CEEPR paper 07-005

Parry IWH (2004) Are emissions permits regressive?. J Environ Econ Manag 47:364-387

Parry IWH, Hilary S, Margaret W, Roberton W III (2005) The incidence of pollution control policies. RFF Discussion Paper 05-24

Poterba JM (1989) Lifetime incidence and the distributional burden of excise taxes. Am Econ Review 79: $325-330$

Shammin MR, Bullard CW (2009) Impact of cap-and-trade policies for reducing greenhouse gas emissions on U.S.Households. Ecol Econ 68:2432-2438

US Census Bureau (2007) Current Population Survey. Annual Social and Economic Supplement. Table HINC06. Revised August 28, 2007. Available http://pubdb3.census.gov/macro/032007/hhinc/new06_000.htm

US EPA (2007) Inventory of US greenhouse gas emissions and sinks: 1990-2005. Available http://www.epa. gov/climatechange/emissions/downloads06/07ES.pdf

West SE, Williams RCIII (2004) Estimates from a consumer demand system: implications for the incidence of environmental taxes. J Environ Econ Manag 47:535-558

Wier M, Birr-Pedersen K, Jacobsen HK, Klok J (2005) Are $\mathrm{CO}_{2}$ taxes regressive? Evidence from the Danish experience. Ecol Econ 52:239-251 